IFN Working Paper No. 852, 2010

\title{
FDI and Growth in East Asia: Lessons for Indonesia
}

Robert E. Lipsey and Fredrik Sjöholm 


\title{
FDI and Growth in East Asia: Lessons for Indonesia*
}

\author{
Robert E. Lipsey, NBER and City University of New York \\ Fredrik Sjöholm, Research Institute of Industrial Economics, Stockholm, \\ and Örebro University
}

\begin{abstract}
Foreign direct investment has been important in the economic growth and global economic integration of developing countries over the last decades. Both Northeast and Southeast Asia, especially the latter, have been part of this development with increasing inflows of FDI and greater foreign participation in their economies. However, Indonesia has been an outlier within the region, with lower inflows of FDI than other countries, especially in manufacturing, and with lower inflows than could be expected from its size and other country characteristics. The inflows of FDI that have taken place have benefited Indonesia and we use the Asian experience to provide some suggestions as to what measures would increase FDI. A relatively poor business environment with inefficient institutions seems to be an important explanation behind the low inflows of FDI.

Keywords: East Asia; Northeast Asia; Southeast Asia; Indonesia; Foreign Direct Investment; Multinational Firms

JEL codes: F23; F13; O19
\end{abstract}

\footnotetext{
* We are grateful for comments and suggestions by Chris Manning and two anonymous referees. Jing Sun and Takuya Hasebe have helped us with excellent research assistance. Fredrik Sjöholm gratefully acknowledges financial support from the Torsten and Ragnar Söderberg Foundation.
} 


\section{INTRODUCTION}

Foreign direct investment (FDI) has been a key aspect of increased globalization in recent decades. The growth in FDI has been higher than growth in international trade; multinational firms have come to account for about 10 percent of world output and 30 percent of world exports; and a large share of new technologies is developed and controlled by these firms.

FDI has played, and continues to play, a large role in Asian development. China is one of the world's largest recipients of FDI and Japan is a major source. Some countries in the region, such as Singapore, have based much of their development strategy on reliance on foreign multinational firms. Finally, Asia is a prime home to multinational firms' cross-country networks, where different affiliates of a firm produce different parts and components, or assemble such parts and components imported from abroad.

FDI often requires coordinating complicated operations over long distances: input goods and services need to be shipped between different branches of the multinational firm; and coordination and supervision requires visits by staff and a steady flow of information. It is clear that the complexities of operations across national borders put large requirements on the host country economic environment. Countries differ in their ability to attract FDI, depending on characteristics such as infrastructure, trade regimes, labor force skills, and institutional quality.

It should therefore not come as a surprise that inflows of FDI differ substantially among countries in Asia. Indonesia is a country where FDI inflows have been relatively modest, and lower than what would be expected from the size of the country. This paper 
tries to explain the low inflows of FDI by relating the situation in Indonesia to the experience of other countries in the region. Asia is a heterogeneous region and countries differ in many aspects. This provides a possibility to evaluate the determinants of FDI. What factors are typically the most important ones in explaining FDI inflows into East Asia?

The paper starts with a description of FDI in East Asia, divided between Northeast and Southeast Asia, and continues with a discussion on the main determinants to FDI in East Asia. Section three includes an analysis of FDI inflows to Indonesia where we compare actual inflows of FDI from different sources with inflows predicted from country characteristics. We continue with a survey of the literature on the impact of FDI on the Indonesian economy. FDI has benefitted the Indonesian economy in various respects and a natural conclusion is that Indonesia would benefit from higher inflows. We then continue with a policy discussion where, on the basis of the previous section on determinants of FDI in East Asia, we examine and discuss possible policies to increase inflows of FDI to Indonesia. The paper ends with a concluding section.

\section{FDI IN THE GROWTH OF DEVELOPING EAST ASIA}

The three main regions of the developing world, Asia, except Japan, Latin America, and Africa, have fared very differently since the middle of the $20^{\text {th }}$ Century. As late as only four decades ago, Latin America had the highest per capita income, there was a good deal of optimism about Africa, and Asia was far behind Latin America. By the early 2000s, Northeast Asian countries had about caught up with Latin America, 
Southeast Asian countries were not far behind, and some had far outstripped Latin America. Incomes in both groups of Asian countries far surpassed those in Africa. ${ }^{1}$

Most studies find FDI to have been a source of the rapid growth of some Asian countries. ${ }^{2}$ That has been the case for most of the countries in the region, although less so and later for the Republic of Korea and Taiwan, which initially followed the Japanese model of restrictions on foreign-controlled firms and only began catching up to the other countries in the region after 1990.

As can be seen in Chart 1, inflows of FDI to East Asia have risen since the 1970s, with interruptions, and accelerated after the opening of China around 1990. The inflow was set back briefly in the mid-1970s, again in the mid-1980s, and by the 1997 crisis, and then again, by the troubles of the IT industry in the early 2000s, a major beneficiary of the FDI capital inflow. The current financial crisis has left its mark, although through 2008, the aggregate flow to the region had remained remarkably resilient. The inflow declined in 2009, but remained close to the highest levels.

-- Chart 1 about here --

A crude measure of the role of inward FDI in different East Asian countries is the ratio of the inward stock to GDP, shown in Table 1. Among the developing regions of the world, Asia became a major destination for flows of FDI well before other regions did. The inward stock of FDI in 1980, for example, was about 42 percent of GDP in Northeast Asia and 9.5 percent in Southeast Asia when it was 8 percent of GDP in Africa and 6.5

\footnotetext{
${ }^{1}$ See the Penn World Tables for data on per capita incomes. http://pwt.econ.upenn.edu/

${ }^{2}$ See, for example, among many, the country studies in Ito and Krueger (2000), Urata, Chia, and Kimura (2006), and Zhang (2001).
} 
percent in South America. By 1995, Southeast Asia had caught up with Northeast Asia, and the ratios to GDP were 22 percent in Southeast Asia, 21 percent in Northeast Asia, 15.6 percent in Africa, and 8.6 percent in South America.

A major part of the growth of FDI in the region was the growth in China. China has been the developing world's largest recipient of FDI in the last decade (UNCTAD, 2009, Appendix Table B-2). However, the growth in FDI to China started from a situation with almost no existing FDI. Despite the large flows, China's stock of inward FDI relative to its size, measured by income, is still not very high by Asian standards.

The largest ratios were those for the two entrepôts, Hong Kong, where a large share of the FDI inflows presumably ended up in China, and which we have combined with China in the table, and Singapore, in which, as in Hong Kong, much of the FDI financed productive assets that were located in other Asian countries. They were followed by Vietnam (although we consider that country's published ratios doubtful), Thailand and Malaysia. Indonesia has a substantially lower ratio of FDI compared to these three neighboring countries. With a ratio of about 13 percent, Indonesia is similar to the Philippines and to the latecomers to FDI inflows, Taiwan and Korea.

-- Table 1 about here --

An alternative measure of the importance of FDI to a country the ratio to capital formation. This is shown for different periods in Table 2. The ratios of FDI to total capital formation have been higher in Southeast than in Northeast Asia since 1980. In 2005-2009, the ratio was more than twice as high. FDI flows were very high in Hong 
Kong and Singapore relative to capital formation, again because much of the capital formation financed by the FDI took place in other locations. The ratios are relatively high also in Vietnam, Malaysia and Thailand. The ratio of FDI to capital formation has increased over time in Indonesia: from about one percent in 1980-84 to eight percent in 2005-2009. This increase notwithstanding, the ratio is lower in Indonesia than in all the other countries except Taiwan and Korea.

-- Table 2 about here --

Another indicator of the extent of inward FDI, calculated by UNCTAD for 2005 and earlier years, is what is referred to as "transnationality", a combination of several ratios of inward FDI activity to country characteristics, including FDI inflows as a percent of gross fixed capital formation, 2003-2005, inward FDI stocks as a percent of GDP in 2005, value added in foreign affiliates as a percent of GDP in 2005, and employment in foreign affiliates as a percent of total employment in 2005. A high figure on the transnationality index means a large presence of inward FDI. The average figure for developing countries in East Asia is approximately 25.5, and ranges from 104 and 65 in Hong Kong and Singapore, to about 8.5 in Indonesia, the least transnational of the North- and Southeast Asian countries by this measure.

\section{WHY HAS SO MUCH FDI GONE TO EAST ASIA?}

A fundamental criterion for attracting FDI is that the host country welcomes such investments. This has not always been the case in East Asia. Developing countries for a 
long time used import substitution to encourage formation and growth of domestic firms. A natural part of this strategy was to restrict access of foreign multinational firms to the domestic market and to use other methods to acquire foreign technology. Japan used this strategy successfully, and that success had a strong impact on development strategies in other countries across East Asia in the 1960's and 70's.

Some Asian countries eventually experimented with a different development strategy, including a stronger reliance on foreign multinational firms. Singapore pioneered this development. When Singapore was expelled from Malaya in 1965 it lost most of its previous domestic market on the Malaysian peninsular and its:

“...original economic strategy, which was reflected in its first ...development plan, became inoperative...Clearly, import replacement made no sense for a citystate....the most rapid economic progress seemed to lie in industrialization...The question was how to bring it about. The decision was made to encourage FDI..." (Krause, Koh, and Yuan, 1987, p. 3).

The economic success of Singapore inspired other countries in East Asia to liberalize their trade regimes and to encourage the entrance of foreign multinational firms. The FDI regimes still differ among East Asian countries, with some being more open than others, but all countries have become more open to FDI over time (Brooks and Hill, 2004). The exact reason for a more liberal FDI regime varied among different East Asian countries. In some it was an attempt to augment domestic savings, in others to 
encourage technology transfer or to get access to international markets for exports (Dobson, 1997).

As previously mentioned, openness to FDI is a necessary condition for attracting foreign multinational firms, but it is not sufficient. The host country needs to provide an economic environment that is attractive for multinational firms. One set of indicators of the environment for business in general is the World Bank's calculations of the ease of doing business, published annually. The major regions of the developing world have differed substantially over the years with respect to the ease of doing business, a characteristic that summarizes many of the obstacles and advantages of the country's institutions. The average rankings of the four main developing regions, with low numbers representing relative ease of doing business, are summarized in Table 3. Northeast Asia was the easiest region for doing business and its average rank has been falling (that is, improving). It is followed by Southeast Asia, the second highest of the developing regions, then by Latin America and finally by Africa, the most difficult environment for business. The margin by which East Asia leads the other developing areas has increased over the period.

Looking at individual country rankings for the quality of the business environment rankings within Asia, it is seen that Singapore is ranked highest of all countries included in the survey and Hong Kong is ranked as number three. Korea, Thailand and Malaysia have also quite low ranks and are considered to have good business environments. Indonesia does not come out favorably in the ranking: it was ranked as number 122 out of 183 included countries. China, Vietnam and the Philippines 
are also considered to have relatively poor business environments but only the latter country is ranked worse than Indonesia.

-- Table 3 about here --

A feature of the recent development of East Asian economies has been their participation in global production networks of multinational firms from the developed countries, particularly U.S. and Japanese firms (Athukorala, 2005; Zhou and Lall, 2005). Multinational firms locate different parts of the production process in different Asian countries to increase efficiency and reduce costs. One consequence of this "fragmentation" of multinational firms' production is to reduce the importance of country size in the location of production, since a small country can participate by specializing in a single stage of production for eventual use in many markets.

A series of papers by Ando and Kimura, summarized in Ando, Arndt, and Kimura (2006), emphasizes the importance of the growth of trade in machinery parts and components, and contrasts that trend in Asian trade with its absence in Latin American trade. When countries are arrayed in the order of importance of machinery and machinery parts and components in their exports, seven Asian countries are above the median, and only one, Indonesia, is below. Among Latin American countries, only one country, Mexico, showed a high ratio and nine a low ratio. Athukorala (2005, p. 9) shows that East Asia's share of global trade in parts and components increased from 34.5 percent in 1990 to 39.5 percent in 2000 . The bulk of trade in parts and components is conducted by multinational firms. 
Electronics has been the most important sector for international production networks. International electronic firms were already in the 1960' and 70 's looking at possibilities to locate labor intensive parts of the production in foreign countries. East Asian countries were the prime location for these firms. For instance, Texas Instruments, and National Semiconducters, located production in Singapore already in the 1960s (Sjöholm, 2003a). They were attracted to Singapore by subsidies but also by an efficient bureaucracy that, for instance, enabled Texas Instruments to start production 50 days after their investment decision (Huff 1994, p. 325).

Malaysia also became an important destination of foreign electronic companies at a relatively early date. One important location was the southern Malaysian state Johor. This development was partly a result of strong historically links with Singapore but it was also made possible through liberalizations of trade and border procedures in Malaysia and through investments in infrastructure on both sides of the border (Sjöholm, 2003a, p. 109). MNEs were able to ship goods back and forward between plants on both sides of the border. Similar networks have over time been spreading to, for instance, China, Thailand, Philippines, and Vietnam.

The cost of production is particularly important for location of vertically integrated production networks, and the cost depends on a host of factors including wages, productivity, infrastructure, tariffs, and taxes. The authors in Ando et al. (2006) associate success in participating in these production-sharing arrangements among countries to FDI environments in host countries, especially to the presence of supporting infrastructure, including "costly communications and coordination infrastructure" (p. 7). 
Labor costs depend on productivity as well as on wage rates. Productivity is highly dependent on the educational level of the workforce and several papers find education and skills of the workforce to be important in multinational firms' location decision. ${ }^{3}$ The level of education varies, of course, with the type of production, but even relatively simple manufacturing typically requires at least basic literacy and numeracy. For more sophisticated production, the skill requirement of the workforce is higher. ${ }^{4}$

Many East Asian countries were early leaders in the education of their populations. They have, for instance, since the 1960s had high levels of completion of secondary education compared to Latin America, Africa, and South Asia, and high levels of completion of tertiary education relative to all developing areas except Latin America (Barro and Lee, 2010, Table 3). This early lead in education may have been part of the reason for the early attractiveness of some of these countries to investors. One should note, however, that the level of education differs within East Asia with a relatively higher level in Northeast than in Southeast Asia (Booth, 1999a and 1999b).

A number of studies try to identify additional determinants of FDI. For instance, Gastanaga et al. (1998) find a general negative effect of corruption on FDI in developing countries. Woo and Heo (2009) examines corruption in eight Asian countries and find also a negative effect on FDI inflows. Hines (1995), in a study on U.S. FDI, and Wei (1997), in a study on OECD, arrive at similar findings. The negative effect of corruption on FDI might seem like a paradox considering that large inflows of FDI and high levels of corruption coincides in many East Asian countries. One explanation is that other

\footnotetext{
${ }^{3}$ See World Bank (2007, p. 180-181) for a discussion of skills and FDI in East Asia.

${ }^{4}$ It is also worth noting that several studies find that a more educated workforce increases the positive impact of FDI on the host economy. For instance, Zhang (2001) and Blomström and Kokko (2003a) stress that the growth effect of FDI is higher in East Asia than in Latin America because education is superior in the former region.
} 
country characteristics, such as cheap labor and large markets, make up for the negative effect of corruption. Another explanation might be the nature of corruption in East Asia. Rodriguez et al. (2005) examines corruption from two dimensions: pervasiveness and arbitrariness. High pervasiveness of corruption makes it institutionalized and predictable whereas arbitrarily corruption increases uncertainty. Corruption in East Asia tends to be of a predictable sort: firms tend to know who to bribe, and once the payment is done the firm will be free from making similar payments to other actors. Lee and Oh (2007) argues that this predictability is especially important for foreign multinational firms with comparable poor knowledge about local conditions: arbitrariness and uncertainty whether bribery will be favorable hurts foreign firms, with relatively poor knowledge of local conditions, more than local firms.

The "Corruption Perceptions Index" published each year by Transparency International suggests that there have been persistent differences among the regions in the perception of the prevalence of corruption (Table 4). The index is constructed from surveys and ratings by risk agencies and country analysts, combined to fit into a scale ranging from 0 to 10 , with 0 representing the highest level of corruption and 10 the lowest. Among the developing regions, Northeast Asia has been perceived as least corrupt since 2001, followed by Southeast Asia. Africa has been perceived as most corrupt. The ordering of the regions in this respect matches the ordering in ratios of inward FDI to GDP.

With respect to the prevalence of corruption, figures on individual countries in Table 4 suggest that there are three groups of countries: Singapore and Hong Kong with low perceived corruption; Taiwan, Korea and Malaysia with intermediate levels of 
corruption; and China, Indonesia, Philippines, Thailand, and Vietnam with relatively high level. Indonesia had the highest level of corruption in 2001 but has made some progress and corruption is in 2009 seen to be similar to the level in Vietnam and lower than in the Philippines.

-- Table 4 about here --

Other studies also highlight the importance of institutions. Chantasasawat et al. (2004) examines FDI to eight East Asian countries between 1985 and 2001. Their results suggest that various institutional factors are among the most important determinants to FDI. For instance, low corporate taxes, low levels of corruption, and a high degree of openness to the international economy increase FDI. One explanation of the relationship lies in the above-mentioned production networks. Such networks rely on low tariffs and low transaction costs to be able to ship parts and components economically among affiliates in different countries.

It is a major task for a developing country to implement all the policies discussed above. A number of East Asian countries have tried to use export processing zones (EPZ) as a way to address this difficulty. The idea behind these zones is that foreign firms are attracted to certain geographic locations in a country where improvements in infrastructure can be concentrated and where the firms often are given special treatment in terms of taxes and regulations. Typical advantages of locating in EPS's include, lower levels of import and export restrictions, less restrictive labor requirements, lower taxes, 
liberal ownership regulations, liberal foreign exchange regulations, and access to superior infrastructure and communication technologies (Madani, 1999).

Countries like Malaysia and Thailand have for a relatively long time relied heavily on export processing zones. Other countries, such as Vietnam, have started later but also been relatively successful. China is perhaps the most successful example where such zones where instrumental in the country's rapid growth. Foreign firms were coming in large numbers to the four zones opened in 1980 and later to new zones that opened up at rapid pace in the coastal provinces. As a result, foreign firms share of export rose from 1 percent in 1985 to more than 50 percent in 2005 (Hofman, Zhao and Ishihara, 2007).

It seems that EPZ's are particularly important in countries with poor institutions. In those instances, EPZs will allow foreign multinational firms to overcome some of the domestic regulations and constraints. As countries develop, the situation in the surrounding economy tends to converge to the EPZ's and the role of EPS's tends to decline.

To sum up the above discussion, in all the characteristics described here as attractive to investment by multinational firms, East Asian countries as a group have been, for at least several decades, superior to other developing regions. That has been the case for the education of the labor force, the control of corruption, the atmosphere for conducting business, the reliability of the infrastructure needed for coordinating chains of supply and production, and the willingness to make changes in institutions to attract foreign firms. The result has been a higher presence of foreign multinationals than in other areas of the developing world. 


\section{INDONESIA AS A RECIPIENT OF FDI}

We have showed that FDI inflows have been large to most countries in East Asia but relatively modest to Indonesia. Another way of describing Indonesia's record in attracting inward FDI is by comparing inward stocks over time with what might be predicted from equations relating the expected inward stock to several possible determinants of inflow of FDI.

In one of these calculations, the variables used for the prediction are the real GDP of the country five years earlier, the growth in real per capita GDP in the previous five years, and a measure of the openness of the economy's trade policy we refer to as "Residual Openness." The measure of "residual openness" is the residual from an equation relating a standard measure of openness, the ratio of exports plus imports to GDP, to a country's population and land area. It takes account of the fact that larger countries, in terms of both population and land area, trade less, relative to GDP, than small countries with the same degree of deliberate trade restriction. It is an attempt to come closer to trade policy than a simple ratio of trade to output.

An example of such a regression is one for the nominal inward FDI stock in a country in year $t$ based on estimating equation (1):

$$
\text { FDI Inward Stock } k_{t}=\alpha+\beta_{1} G P_{t-5}+\beta_{2} \text { per capita growth } h_{\mathrm{t}-4}+\beta_{3} \text { Res.Op }_{\mathrm{t}-5}
$$

The actual inward stock of FDI in Indonesia in 1985 as reported in the UNCTAD data base (from www.unctad.org/fdistatistics) was 31 percent of the stock predicted by the equation and reached 40 percent of the predicted stock by 2005, when actual levels 
for four East Asian countries were higher than predicted levels and only the Philippines had a lower ratio of actual to predicted FDI stock (Table 5).

--Table 5 about here--

The data on aggregate stocks and flows of FDI to individual countries are subject to many problems of measurement and interpretation. For some countries, part of the FDI inflow does not add to the productive assets of the nominal destination country, but flows through to other countries, where the labor and physical capital financed by the flow end up. That is the case, for example for inflows to Hong Kong and Singapore. In other cases, the inflows never reach the supposed destination country, except as notations on accounting statements.

For FDI from the United States, more information is available about the composition and characteristics of the FDI flows and stocks. The main advantage is that we can the study real activities of multinational affiliates rather than looking at financial flows. Predictions of the levels of total employment in U.S. affiliates and employment in manufacturing affiliates can be made, based on the same independent variables as for the total stock of inward FDI, and these can be compared with actual surveys of U.S. multinationals.

Employment in all U.S. affiliates in Indonesia ranged from about half the predicted level to a peak of 90 percent (not shown). For no other Northeast or Southeast Asian country was the underprediction of U.S. affiliate employment consistently greater. For U.S. firms in manufacturing, their employment in Indonesia was only 11 percent of 
the expected number in 1985 , but it increased steadily to over 80 percent of the expected amount in 2005, close to the median.

In contrast, the level of physical capital in U.S. affiliates in Indonesia, as represented by net property, plant, and equipment, was far above the predicted values in all the years from 1985 through 2005. That contrast is, as discussed below, explained by the division of U.S. FDI into investment in manufacturing and in other industries. Employment in U.S. manufacturing affiliates in Indonesia fell far short of predicted values, as little as 11 percent in 1985 , but gradually came closer to the prediction by 2005. It was only a fraction of the affiliate manufacturing employment in such small economies as Hong Kong and Singapore, until a more than doubling from 2000 to 2005 brought it above both of those.

The composition of U.S. firms' employment in Indonesia was very different from that in other East Asian countries (Table 6). The share in mining was much higher, at least over 23 percent, although data suppression conceals the actual level. In no other country in the region was the share over 2 percent. The share in Machinery is particularly low, at less than half of one percent, while in other countries, except the Philippines, it ranged from 2 to 6 percent. Computers and electronic products accounted for less than 1 percent of employment in US firms' affiliates, while the shares in the other countries ranged from 3.5 percent in Hong Kong to over 50 percent in Malaysia. In general, the investment in Indonesia from the United States avoided the manufacturing industries in which technology was important, with the exception of Chemicals, probably drawn to the country by the petroleum investments. Furthermore, the low share of US FDI in electronics suggests that Indonesia is not part of US production networks. 
--Table 6 about here--

The omission of Indonesia from U.S. multinationals' production networks is supported in Table 7 by the low share of sales outside the host country in total sales of manufacturing affiliates in Indonesia. U.S. manufacturing affiliates in Indonesia made about 20 percent of their sales outside the country, while manufacturing affiliates in Taiwan and Thailand made over $45 \%$ of their sales abroad and those in the other East Asian countries except China and Korea made over $50 \%$ of their sales outside their home markets.

--Table 7 about here-

We did also examine inflows of FDI from countries where similar data on activities in foreign affiliates are available. The results above of lower inflows of FDI than what could be expected were largely confirmed. ${ }^{5}$ For instance, German FDI in Indonesia was lower than would be expected from a prediction based on FDI in all developing countries, whereas employment in Japanese-owned manufacturing plants in Indonesia was close to predicted levels.

The variables included in the predictions described above refer to Indonesia as a maket for the investing firms and therefore capture mostly market seeking FDI. However, our results are confirmed in other studies using broader sets of variables that reflect also Indonesia's attractiveness as a location for export-oriented production. For instance,

\footnotetext{
${ }^{5}$ The results are available upon request.
} 
Indonesia exhibits underperformance in terms of FDI inflows, compared to what one would expect from country characteristics, according to UNCTAD (2010). They rank Indonesia as number 119 out of 141 countries in terms of FDI inflows. This figure could be compared to what UNCTAD refers to as the potential inflows of FDI, which is based on 12 different economic and policy variables, where Indonesia is ranked as number 85 .

The history of FDI in Indonesia has thus been one of relatively low participation of foreign firms, as compared with their role in other countries in the region. Indonesia is not the country most closed to foreign firms, but it ranks low as a location for FDI in general and for participation in chains of production organized by foreign firms. The modest inflow of FDI to Indonesia stands in sharp contrast to the neighboring countries which are all characterized by a heavy concentration of MNEs.

\section{THE EFFECT OF FDI ON THE INDONESIAN ECONOMY}

It would be in Indonesia's interest to increase inflows of FDI only if such inflows benefits the country. We therefore briefly survey the literature on the effects of FDI in Indonesia. Table A1 in the appendix shows a number of studies that look at different effects of FDI.

The empirical literature shows surprisingly consistent benefits of FDI to Indonesia. For instance, foreign firms bring in new production processes or start to produce new products benefits the country and will manifest itself in relatively high productivity in foreign firms. A number of studies show that this is indeed the case: foreign firms have higher labor productivity and higher total factor productivity than local firms. Moreover, not only the level but also the growth of productivity is high in 
foreign firms. Finally, all of the listed studies find productivity to be high even after controlling for various firm characteristics, such as size and capital intensities.

Previous literature also shows a clear difference in export intensities: foreign firms are substantially more integrated in the international economy through exports. This is not surprising but a result found in most countries. One interesting finding on Indonesia is that even foreign firms that start producing only for the Indonesian market are more able to switch to export than are local firms.

Foreign-owned establishments in Indonesia pay also higher wages than domestically owned establishments, even given the educational level of their labor forces. They also pay a higher premium the higher the level of education. Foreign firms' entry thus not only increases wages, but also increases the returns to education and encourages workers' investments in additional education. Accordingly, foreign acquisition of an Indonesian manufacturing plant results in higher wages for the plant's employees. Hence, foreign ownership and foreign acquisition increase wages relative to domestic ownership.

A similar story applies to growth in employment. Foreign firms have relatively high growth in employment and foreign acquisitions of domestic firms increase growth in employment, despite that foreign-owned firms are relatively large and large firms tend to have relatively low growth rates in employment.

The studies in Table A1 suggest that foreign firms have high productivity and export, pay high wages, and show a high growth in employment. If local firms benefit from FDI, it is clear that there are gains to the country from hosting foreign multinational firms, but the benefits are less clear if local firms are instead hurt by the presence of foreign firms. The effects of FDI on local firms are often expressed as spillovers. Positive 
spillovers could for instance arise from transfer of technologies from foreign to domestic firms or from expanding markets for domestic suppliers of intermediate goods. Negative spillovers could result from increased competition which forces domestic firms out of business or forces them to operate at a lower scale of production.

Table A2 in the appendix summarize existing studies on spillovers in Indonesia. ${ }^{6}$ Most studies focus on the effect on productivity but there are also two studies on wage spillovers. Almost all of the studies find evidence of positive spillovers: local firms benefit from the presence of foreign firms within the industry or region. For productivity, the positive effect is likely to come from technology spillovers, new technologies and knowledge that are made available for domestic firms, and from increased competition, a pressure to improve to secure market shares and survival. For wages, the positive effect of FDI is likely to be the result both of increased productivity through the discussed spillovers, and thought an increased demand for labor. Since the foreign plants also have higher productivity and pay higher wages than local firms, the two factors together imply that higher foreign presence raises the general productivity and wage level in a province and industry.

\section{POLICY DISCUSSION: HOW COULD INDONESIA ATTRACT MORE FDI?}

If faster growth is an important goal of economic policy, it would seem to be in Indonesia's interest to increase inflows of FDI considering the benefits FDI brings in terms of productivity growth, higher wages and strong employment growth. However, the Indonesian attitude towards FDI has always been rather ambivalent. Indonesia's continuing ambivalence toward FDI is reflected in the fact that in each year's review of

\footnotetext{
${ }^{6}$ See also Lipsey and Sjöholm (2005).
} 
FDI policy in UNCTAD's World Investment Report in the last few years, some added restrictions in Indonesia are mentioned. For example, in the 2008 WIR, "Indonesia extended the list of business activities that are closed and partially restricted to foreign investment" (pp. 52-53). In the 2009 WIR, "In Indonesia...the Ministry of Communications issued a decree barring foreigners from investing in the construction and ownership of wireless communications towers" (p. 56), and in the 2010 WIR, “...some new restrictions to engage in certain activities were introduced (e.g. in India and Indonesia)." (p. 39). Indonesia was the only country mentioned as introducing new restrictions in all three years.

Fiscal incentives are often mentioned when policies to attract FDI are discussed in Indonesia. Such incentives have been used in other parts of East Asia, both in the form of favorable tax treatments and direct subsidies. Fiscal incentives can only be justified if the benefit to the host economy is larger than the cost of the fiscal incentives. Many authors argue that this is seldom the case (Blomström and Kokko, 2003b). Moreover, most studies suggest that fiscal incentives are not important in MNE's localization decisions (Morisset and Pirnia, 1999). One serious problem is that fiscal incentive schemes are difficult to administer and often lead to corruption (Morisset, 2003). The past and present problems with the Indonesian Investment Promotion Agency (BKMP) suggest that such fiscal incentive policies run the risk of being relatively inefficient also in Indonesia.

It is therefore more fruitful to address the general business climate in Indonesia. Our previous discussion on determinants of FDI in East Asia suggested that high levels of education, good institutions, and openness to trade are all important factors in the location decision of multinational firms. 
Education is very poor in Indonesia. The exception is enrolment in primary education which was substantially expanded in the 1970's with the use of public revenues from oil. However, enrolment in tertiary and secondary education has been lower than in most other countries in East Asia (Sjöholm, 2005). Moreover, there are signs that the quality of education is relatively poor (Jones and Hagul, 2001; Welch, 2007).

To illustrate the situation, Table 8 shows that educational attainment, as of 2010, is lower, on average, than in any of the other East Asian countries discussed here. The proportion of the population 15 and over with no schooling is far above that in any other of the countries. Only 1.4 percent of the population has completed tertiary education and the average member of the population has had only a little over 6 years of education, the lowest level among these countries. Only in the completion of secondary education is Indonesia ahead of a few of the other countries. The drop from the proportion completing secondary education to the proportion completing tertiary education is 94 percent, the largest among the nine countries. Either little tertiary education has been pursued or many of those that have pursued it have left the country.

--Table 8 about here--

Improved education is important for attracting FDI but it will also affect Indonesia's absorptive capacity; the better the level of education the more Indonesia will benefit from foreign MNEs. The same can be said about the technological capacity in Indonesia. A higher technological capacity would encourages foreign MNEs to upgrade production to higher value added activities in Indonesia, rather than placing such 
production in other countries, and it would also increase spillovers by facilitating knowledge transfers from MNEs to local firms.

Technological capability is another area where there seems to be large potentials for improvements, which would be positive for attracting FDI. Indonesian technology policies before the Asian crisis were dominated by large high-tech projects in aircraft, shipbuilding, railroads, telecommunications, electronics, steel and machinery. Poor management and a weak scientific and engineering infrastructure made most of these projects fail (e.g. McKendrick, 1992; Hill, 1995; Hill and Thee, 1998; Okamoto and Sjöholm, 2003). High-tech projects were mostly abandoned after the crisis but no new technology policy has emerged in its place. As a result, Indonesia remains at the bottom of the technology ladder in the region. One indication of the poor state of technology development and technology capability, or perhaps one of the causes, is the very low investment in research and development. The figures shown in Table 9 show that, firstly, $\mathrm{R} \& \mathrm{D}$ as a share of GDP is substantially lower in Indonesia than in the other included countries. Secondly, the share of R\&D has declined in Indonesia between 2000 and 2005, whereas it has increased in all other countries.

Another indication of technological capabilities is the extent to which foreign investors choose to perform $\mathrm{R} \& \mathrm{D}$ in their Indonesian affiliates. An indication of that judgment on the part of U.S. multinational firms is given in Table 9. On average, in 2004, U.S. firms' affiliates in developing Asia spent on R\&D about 11 percent of their expenditures for employee compensation. The highest ratios among these countries were about 19 percent in Singapore and Taiwan. In contrast, affiliates in Indonesia spent on $\mathrm{R} \& \mathrm{D}$ an amount equal to only 0.6 percent of their employee compensation, far below the 
ratios in any other country in the region. The next lowest share was in Thailand, where it was three times as high as in Indonesia. The same stark contrasts can be seen for R\&D expenditures per employee, 5 or 6 thousand dollars per employee in the highest countries, Singapore and Taiwan, but only $\$ 80$ per employee in Indonesia.

-- Table 9 about here --

Infrastructure is a related issue affecting the interest of foreign multinational firms to locate in Indonesia. The importance of infrastructure is clear from the East Asian experience where many countries have used improvements to infrastructure deliberately to attract foreign firms and to integrate in international production networks. It is also clear that many East Asian countries continue to invest heavily in infrastructure and that such investments increased further in for instance China after the outbreak of the global financial crisis in 2008.

Unfortunately, infrastructure is poor in Indonesia. A report on Indonesia in The Economist in 2009 quoted a Jakarta bank executive as saying that infrastructure had become the top obstacle to doing business in Indonesia among his banks' clients.

“...roads, air- and seaports are inadequate...Electricity generation lags demand...Only $18 \%$ of the population have piped water and only $2.5 \%$ are connected to a sewer system...Export industries are hindered by a lack of ports...” (The Economist, September 12, 2009, pp. 11-12). 
The crisis in the late 1990's had a negative effect on investments in infrastructure. However, investments remained very low even after the crisis was over. In 2010, The Global Competitiveness Report ranked Indonesia only as number 96 in terms of the quality of infrastructure, out of 133 included countries. Some signs of an improvement came in 2009 when the government tried to balance a large drop in external demand by launching a program for major infrastructure investments (Resosudarmo and Yusuf, 2009). However, insufficient public funding is only one of many factors that restrain infrastructure development. Other problems that will be difficult to solve include a lack of technical capabilities at responsible local governments, poor coordination between central and local governments and between different regions, and large problems with land acquisitions (Kong and Ramayandi, 2008).

FDI might be one way to improve infrastructure. Investments by foreign firms in infrastructure, and also in utilities, finance, construction and other non-tradables, are affected by various institutional factors such as competition and pricing policies. Complex regulations are often required to attract investments in these sectors. Indonesia has a mixed history in dealing with inward investments in infrastructure projects (Wells and Ahmed, 2006). Lack of administrative capacity, poor regulatory structures and corruption are some of the main causes of failing investments in infrastructure. Wells (2007) suggest some policies to improve upon the investment regime: a closer look at international best practices, a ban on equity arrangements where importantly placed Indonesians get a share of foreign investments, and an institutional arrangement where only one government agency has the full responsibility to negotiate and make agreements with foreign investors in infrastructure projects. 
The quality of institutions is perhaps the most important determinant to FDI. In a survey of Japanese firms that chose various countries as prospective sites for their foreign manufacturing locations, over 80 percent of those choosing Indonesia listed "Political and Social Environment" as a weak point, far more than for any other location (Kimura and Ando, 2006, Table 2.8). Indonesia has traditionally been seen as having some of the world's most corrupt institutions (Butt, 2009). The figures in Table 4 supports this view. ${ }^{7}$ In a comment on corruption in Indonesia in 2008, Transparency International (2008) notes that Indonesia is plagued by rampant corruption, but with some signs of improvements during recent years. Despite this possible slight improvement, corruption remains a real problem and some recent reports indicate new setbacks when the police force, the parliament, and the attorney general's office have been obstructing the work of the anti-corruption commission (Patunru and von Luebke, 2010).

It is difficult to know exactly how negative corruption is for FDI inflows to Indonesia but there are ample of anecdotal stories of foreign firms who do not invest in Indonesia for fear that corruption will lead to bad-will or with problems with home country authorities (e.g. Wells, 2007, p. 354).

There are also reasons why the changing nature of corruption might be negative. Corruption was high under the New Order regime but it was also highly institutionalized and predictable: once a standard contribution to the Suharto family or its closest allies had been made, the regime made sure that the foreign firms' activities were not disturbed (World Bank, 2003; Lee and Oh, 2007)). Corruption after Suharto is mainly caused by local governments' regulations (Henderson and Kuncoro, 2004). Corruption differs

\footnotetext{
${ }^{7}$ See also Kaufman, Kray, and Mastrurzzi (2009) for a similar view.
} 
between provinces and districts, is highly arbitrarily, and therefore more difficult for foreign multinationals to deal with.

As previously said, the business environment is generally seen to be poorer in Indonesia than in other East Asian countries. For instance, the Foreign Policy magazine Globalization Index is an indicator of investors' perception of the investment climate in different countries and are often said to be closely watched by the international community. ${ }^{8}$ Indonesia was ranked as number 86 out of 156 countries and behind all included countries in East Asia except Cambodia and Vietnam.

The government has since 2006 tried to reform the investment climate for foreign firms. Some reforms of particular importance are the equal treatment of foreign and domestic investors and the streamlined application procedures for investment approvals (Lindblad and Thee, 2007). However, 25 sectors are closed to foreign firms. More importantly, Indonesia still uses ownership sharing requirements for foreign investments (Takii and Ramstetter, 2007). Ownership sharing has been abandoned in many other countries, since they don't provide any additional benefits to the host economy, and might deter inflows of FDI (Blomström and Sjöholm, 1999). Foreign firms that are afraid of losing their technologies to domestic actors, will think twice before they engage in a joint venture with local actors.

The problems for foreign firms are often caused by local authorities. With the decentralization of Indonesia in 2001, the quality of public policies and economic governance differ markedly across regions in Indonesia. Some local governments have been encouraging local and foreign firms, whereas many others have constrained firms

\footnotetext{
${ }^{8}$ See http://globalization.kof.ethz.ch/
} 
by imprudent taxation, corruption and inefficient bureaucracy (von Luebke, 2009). Good local leadership seems to make a very big difference in fostering a good business environment. For instance, business licenses could be obtained in only two days for only Rp 5,000 in Yogyakarta, compared to 20 days in Medan and at a cost of Rp 477,000 in Bandung. Moreover, good local leadership in the west Sumatran district Solok has avoided poor regulations and corruption, and has significantly improved upon the private sector business environment. ${ }^{9}$

As discussed in the paper, openness to trade is another important determinant of FDI, especially for multinational firms with vertically integrated production chains. The trade regime in Indonesia deteriorated after the crisis in 1997-98 with increased corruption at the customs services and with increased time and costs for clearing goods (Athukorala, 2002). In recent years, the situation seems to be improving. One of the included criteria in the World Bank's doing business survey is trading across borders, which is defined as the documents, time and cost to export and import. Indonesia is ranked as number 45 , hence substantially better than its average ranking of 122 . It is also better than the ranking of many other countries in the region, and about the same ranking as China (rank 44). A slightly worrying sign, however, is that Indonesia dropped from rank 40 in 2007. Poor integration in the international economy is presumably one reason why Indonesia in not participating in international production networks to the same extent as many other East Asian countries. ${ }^{10}$

\footnotetext{
${ }^{9}$ See van Luebke (2009) and the references therein.

${ }^{10}$ There are exceptions. A relative large number of foreign electronic firms have located themselves in the Export Processing Zones Bintan and Batam islands. These islands are located just half an hour by speed boat from Singapore and are a part of the Singapore-Johor-Riau growth triangle (Thambipillai, 1998).
} 
Furthermore, it is likely that historical poor policies explain part of the development. It is here interesting to note that Indonesia was an early receiver of foreign multinational firms in electronics. For instance, Fairchild and National Semiconductor established plants in Indonesia in the early 1970's. However, both firms closed their operations in Indonesia in the 1980's because of an unfavorable business environment (Thee and Pangestu, 1998, p. 223).

\section{CONCLUDING REMARKS}

FDI has been important in East Asia's economic development. Multinational firms have contributed to host country development by bringing in new technologies and providing access to foreign markets. The benefits have become increasingly obvious for policy makers over time and explain the changing attitude towards FDI in East Asia: from a negative view where most policies aimed at keeping foreign firms out, to a situation where substantial resources are spent on attracting foreign firms.

Multinational firms have responded to the policy changes and invested heavily in the region. Production networks, where different parts of multinationals' production chain are located in affiliates in different countries, seem to be particularly important in East Asia.

Indonesia has not fully participated in this development and attracts less FDI than what could be expected from its size and growth, particularly in the periods up to 1990 and in recent years. This coincides with a relative restrictive FDI regime and with later failures to continue with liberalizations. In the 1990's, when the FDI regime was substantially liberalized, FDI inflows were larger. 
A survey of the literature shows that FDI has increased economic growth, wages, export, and employment in the Indonesian economy. What could be done if Indonesia wished to attract more FDI? As global and regional competition for FDI has increased, an FDI regime and an economic environment that were sufficient for attracting FDI some years ago are not sufficient today.

An analysis of determinants of FDI in East Asia gives some guidance: good institutions, a skilled workforce, and openness to trade. Some of these are factors where Indonesia has shown improvements in recent years. These improvements, if they are continued and intensified, will presumably make Indonesia more attractive for multinational firms, although it will take time before the improvements have more widespread impact on the economy.

It is important to recognize that the business environment is poorer than in many other East Asian countries. Indonesian institutions need to be improved further. Corruption is one area with some small signs of improvements, but where the situation remains worse than in most other countries in East Asia. Poor institutions and corruption increase the costs of production. Multinational firms that can choose between different locations will tend to stay out of Indonesia unless these issues are addressed. To end the paper on a positive note, there are some provinces that in recent years have been able to implement good policies and improve local institutions. To use these good examples for reforms and changes at a national level would increase inflows of FDI and thereby be fruitful for the continued development of Indonesia. 


\section{REFERENCES}

Aitken, B.J., Harrison, A.E. and Lipsey, R.E. (1996) 'Wages and Foreign Ownership: A Comparative Study of Mexico, Venezuela, and the United States', Journal of International Economics 40(3-4): 345-71.

Ando, M., Arndt, S.W. and Kimura, F. (2006) 'Production Networks in East Asia: Strategic Behavior by Japanese and U.S. firms', Discussion Paper No. 103, .JCER Multinational Firms' Strategies in East Asia: A Comparison of Japanese, U.S. European, and Korean Firms JCER Discussion Paper No. 103, Tokyo, June 1, 2006. A later expanded version was published (in Japanese) in Kyoji Fukao and JCER, editors, Japanese Firms' Strategy in East Asia: A Comparison with US and European Firms: NihonKeizai Shinbun Sha

Arnold, J.M. and Beata Javorcik S. (2009) 'Gifted Kids or Pushy Parents? Foreign Acquisitions and Plant Performance in Indonesia', Journal of International Economics, forthcoming.

Aswicahyono, Haryo and Hal Hill (2002), 'Perspiration versus Inspiration in Asian Industrialisation: Indonesia before the Crisis' Journal of Development Studies, 38 (3): $138-163$.

Athukorala, P. (2002) 'Survey of Recent Developments', Bulletin of Indonesian Economic Studies 38(2): 141-162.

Athukorala, P.(2005) 'Product Fragmentation and Trade Patterns in East Asia', Asian Economic Papers 4(3): 1-27.

Barro, Robert J. and Jong-Wha Lee (2010), "A New Data Set of Educational Attainment in the World, 1950-2010, Cambridge, MA, NBER Working Paper 15902, April.

Blalock, G. and Gertler, P.J. (2008) 'Welfare Gains from Foreign Direct Investment through Technology Transfer to Local Suppliers', Journal of International Economics 74(2): 402-421.

Blalock, G. and Gertler, P.J. (2009) 'How Firm Capabilities Affect Who Benefits from Foreign Technologies', Journal of Development Economics, forthcoming.

Blomström, M. and Kokko, A. (2003a) 'Human Capital and Inward FDI', CEPR Discussion Paper No. 3762, Centre for Economic Policy Research, London.

Blomström, M. and Kokko, A. (2003b) 'The Economics of Foreign Direct Investment Incentives', Stockholm School of Economics, EIJS Working Paper 168.

Blomström, M. and Sjöholm, F. (1999) 'Technology Transfer and Spillovers: Does Local Participation with Multinationals Matter?', European Economic Review 43(4-6): 915-23.

Booth, A. (1999a) 'Education and Economic Development in Southeast Asia: Myths and Realities', ASEAN Economic Bulletin 16(3): 290-306.

Booth, A. (1999b) 'Initial Conditions and Miraculous Growth: Why is South East Asia Different from Taiwan and South Korea?', World Development 27(2): 301-322.

Brooks, D.H. and Hill, H. (2004) 'Divergent Asian Views on Foreign Direct Investment and Its Governance', Asian Development Review 21(1): 1-36.

Butt, S. (2009) 'Unlawfulness and Corruption under Indonesian Law', Bulletin of Indonesian Economic Studies 45(2): 179-198.

Carkovic, M. and Levine, R. (2005) 'Does Foreign Direct Investment Accelerate Economic Growth?' in Does Foreign Direct Investment Promote Development?, 
eds Moran, T.H., Graham, E.M. and Blomström, M., Institute for International Economics, Center for Global Development, Washington D.C.

Chantasasawat, B., Fung, K.C., Iizaka, H. and Siu, A. (2004) 'The Giant Sucking Sound: Is China Diverting Foreign Direct Investment from Other Asian Economies?', Asian Economic Papers 3(3): 122-140.

Dobson, W. (1997) 'East Asian Integration: Synergies Between Firm Strategies and Government Policies', in Multinationals and East Asian Integration, ed. Dobson, W. and Yue, C.S., Institute of Southeast Asian Studies, Singapore.

Gastanaga, V.M., Nugent, J.B. and Pashamova, B. (1998) 'Host Country Reforms and FDI Inflows: How Much Difference Do They Make?', World Development 26(7): 1299-1314.

Henderson, J.V. and Kuncoro, A. (2004) 'Corruption in Indonesia', NBER Working Paper, No. 10674.

Hines, J.R. Jr. (1995) 'Forbidden Payment: Foreign Bribery and American Business After 1977', NBER Working Paper, No. 5266, National Bureau of Economic Research, Cambridge MA.

Hill, H. (1995) 'Indonesia's Great Leap Forward? Technology Development and Policy Issues', Bulletin of Indonesian Economic Studies, 31(2): 83-123.

Hill, H. and Thee, K.W. (1998) Indonesia's Technological Challenge, Institute of Southeast Asian Studies, Singapore.

Hofman, B., Zhao, M. and Ishihara, Y. (2007) 'Asian Development Strategies: China and Indonesia Compared', Bulletin of Indonesian Economic Studies 43(2): 171-199.

Huff, W.G. (1994) The Economic Growth in Singapore: Trade and Development in the

Twentieth Century, Cambridge University Press, Cambridge.

Ito, Takatoshi, and Anne O. Krueger, Editors (2000) The Role of Foreign Direct Investment in East Asian Economic Development, NBER-East Asia Seminar on Economics, Vol. 9, Chicago and London, University of Chicago Press.

Jones, G.W. and Hagul, P. (2001) 'Schooling in Indonesia: Crisis-Related and LongerTerm Issues', Bulletin of Indonesian Economic Studies 37: 207-231.

Kaufmann, D., Kraay, A. and Mastruzzi, M. (2009) Governance Matters VIII: Aggregate and Individual Governance Indicators, 1996-2008, Development Research Group June 2009, World Bank.

Kimura, F., and Ando, M., (2006) 'Japanese Manufacturing FDI and International Production and Distribution Networks in East Asia', in Urata, Chia, and Kimura, Editors. 65-103.

Kong, T. and Ramayandi, A. (2008) 'Survey of Recent Developments', Bulletin of Indonesian Economic Studies 44(1): 7-32.

Krause, L.B., Koh Ai, T., and Yuan, L.T., (1987) The Singapore Economy Reconsidered, Institute of Southeast Asian Studies, Singapore.

Lee, S.H and Oh, K.K. (2007) 'Corruption in Asia: Pervasiveness and Arbitrariness', Asia Pacific Journal of Management 24: 97-114.

Lindblad, T.J. and Thee, K.W. (2007) 'Survey of Recent Developments', Bulletin of Indonesian Economic Studies 43(1): 7-33.

Lipsey, R.E. (2006), 'U.S. Firms and East Asian Development in the 1990s,' in Multinationals and Economic Growth in East Asia: Foreign Direct Investment, ed. 
Urata, S. Chia, Y.S. and Kimura, F. (2006), Routledge, London and New York: 105-129.

Lipsey, R.E. and Sjöholm, F. (2004a) 'Foreign Direct Investment, Education, and Wages in Indonesian Manufacturing', Journal of Development Economics 73: 415-422.

Lipsey, R.E. and Sjöholm, F. (2004b) 'FDI and Wage Spillovers in Indonesian Manufacturing', Review of World Economics 140(2): 321-332.

Lipsey, R.E. and Sjöholm, F. (2005) 'Host Country Impacts of Inward FDI: Why Such Different Answers?', in The Impact of Foreign Direct Investment on Development: New Measurements, New Outcomes, New Policy Approaches, eds Blomström, M., Graham, E., and Moran, T., Institute for International Economics, Washington D.C.: 23-43.

Lipsey, R.E. and Sjöholm, F. (2006) 'Foreign Firms and Indonesian Manufacturing Wages: An Analysis with Panel Data', Economic Development and Cultural Change 55(1): 201-221.

Lipsey, R.E., Sjöholm, F. and Sun, J. (2010) 'Foreign Ownership and EmploymentGrowth in Indonesian Manufacturing', NBER Working Paper No. 15936.

Madani, D. (1999) 'A Review of the Role and Impact of Export Processing Zones',World Bank Policy Research Working Paper No. 2238.

McKendrick, D. (1992) 'Obstacles to 'Catch-Up': the Case of the Indonesian AircraftIndustry', Bulletin of Indonesian Economic Studies 28(1): 39-66.

Morisset, J.P. (2003) 'Using Tax Incentives to Attract Foreign Direct Investment', The World Bank, Private Sector and Infrastructure Network, Viewpoint 253.

Morisset, J.P. and Pirnja, N. (1999) 'How Tax Policy and Incentives Affect ForeignDirect Investment: A Review', World Bank Policy Research Working Paper 2509.

Okamoto, Y. and Sjöholm, F. (2003) 'Technology Development in Indonesia',Competitiveness, FDI and Technological Activity in East Asia, eds Lall, S. and Urata, S. Edward Elgar, London.

Okamoto, Y. and Sjöholm, F. (2005) 'FDI and the Dynamics of Productivity in Indonesian Manufacturing', Journal of Development Studies 41(1): 160-182.

Pantunru, A.A. and von Luebke, C. (2010) 'Surey of Recent Developments', Bulletin of Indonesian Economic Studies 46(1): 7-32

Ramstetter, E.D. (1999) 'Trade Propensities and Foreign Ownership Shares in IndonesianManufacturing', Bulletin of Indonesian Economic Studies 35: 45-66.

Resosudarmo, B.P. and Yusuf, A.A. (2009) 'Survey of Recent Developments', Bulletin of Indonesian Economic Studies 45(3): 285-306.

Rodriguez, P., Uhlenbruck, K. and Eden, L. (2005) 'Government Corruption and the Entry Strategies of Multinationals', Academy of Management Review 30(2): 383396.

Sjöholm, F. (1999a) 'Productivity Growth in Indonesia: The Role of Regional

Characteristics and Direct Foreign Investment', Economic Development and Cultural Change 47(3): 559-84.

Sjöholm, F. (1999b) 'Technology Gap, Competition and Spillovers from Direct Foreign Investment: Evidence from Establishment Data', Journal of Development Studies 36(1): 53-73. 
Sjöholm, F. (2003a) 'Industrial Upgrading in a Globalized Economy: The Case

Of Singapore', in Globalization and its Enemies, ed Lundahl, M., EFI, Stockholm: (99-119).

Sjöholm, F. (2003b) 'Which Indonesian Firms Exports? The Importance of Foreign Networks', Papers in Regional Science 82: 333-350.

Sjöholm, F. (2005) 'Educational Reforms and Challenges in Southeast Asia' in Institutional Change in Southeast Asia, eds Sjöholm, F. and Tongzon, J. (2005), Routledge, London.

Sjöholm, F. and Takii, S. (2008) 'Foreign Networks and Exports: Results from Indonesian Panel Data', Developing Economies 46(4): 428-446.

Takii, S. (2004) 'Productivity Differentials between Local and Foreign Plants in Indonesian Manufacturing, 1995', World Development 32: 1957-1969.

Takii, S. (2005) 'Productivity Spillovers and Characteristics of Foreign Multinational Plants in Indonesian Manufacturing 1990-95', Journal of Development Economics 76(2): 521-542.

Takii, S. (2009) 'Multinationals, Technology Upgrading, and Wages in Urban and Rural Indonesia', Review of Development Economics 13(1): 151-163.

Takii, S. and Ramstetter, E.D. (2005) 'Multinational Presence and Labour Productivity Differentials in Indonesian Manufacturing, 1975-2001', Bulletin of Indonesian Economic Studies 41: 221-242.

Takii, S. and Ramstetter, E.D. (2007) 'Survey of Recent Developments', Bulletin of Indonesian Economic Studies 43(3): 295-322.

Temenggung, D. (2008) 'Foreign Direct Investment and Productivity Spillovers in Indonesian Manufacturing', Ph.D. dissertation, Australia National University, Canberra.

Thambipillai, P. (1998) 'The ASEAN Growth Areas: Sustaining the Dynamism', The Pacific Review 11(2): 249-266.

Thee, K.W. and Pangestu, M. (1998) 'Technological Capabilities and Indonesia's Manufactured Exports', in Technological Capabilities and Export Success in Asia, eds Ernst, D., Galitsis, T. and Mycelia, L., Routledge, London.

Todo, Y. and Miyamoto, K. (2002) 'Knowledge Diffusion from Multinational Enterprises: The Role of Domestic and Foreign Knowledge-Enhancing Activities', OECD Technical Paper No. 196. OECD Development Centre, Paris.

Transparency International (2008), 2008 Corruption Perceptions Index Regional Highlights: Asia-Pacific, accessed at 2009-09-28,

http://www.transparency.org/policy_research/surveys_indices/cpi/2008/regional_highligh ts factsheets

UNCTAD (United Nations Conference on Trade and Development) (2008) World Investment Report, 2008, United Nations, New York and Geneva.

UNCTAD (United Nations Conference on Trade and Development) (2009), World

Investment Report, 2009, United Nations, New York and Geneva.

UNCTAD (United Nations Conference on Trade and Development) (2010) World Investment Report, 2010, United Nations, New York and Geneva.

UNCTAD, (United Nations Conference on Trade and Development), web site www.unctad.org/fdistatistics.

UNESCO (2009), Educational Statistics. Online., accessed at 2009-09-22 
$<$ http://stats.uis.unesco.org/unesco/TableViewer/document.aspx?ReportId=13

$\& I F \_$Language $=$eng $\&$ BR_Topic $=0>$

United States, Bureau of Economic Analysis (2008) U.S. Direct Investment Abroad, 2004: Final Benchmark Data, Washington, DC, Bureau of Economic Analysis.

United States, Bureau of Economic Analysis (2009) U.S. Direct Investment Abroad: Preliminary 2007 Data, Web site of the Bureau of Economic Analysis.

Von Luebke, C. (2009) 'The Political Economy of Local Governance: Findings from an Indonesian Field Study', Bulletin of Indonesian Economic Studies 45(2): 201-30.

Wei, S. (1997) 'Why is Corruption so Much More Taxing than Tax? Arbitrariness Kills', NBER Working Paper Nr. 6255, National Bureau of Economic Research, Cambridge MA.

Wells, L.T. and Ahmed, R. (2006) Making Foreign Investments Safe: Property Rights and National Sovereignty, Oxford University Press, New York.

Wells, L.T. (2007) 'Private Power in Indonesia', Bulletin of Indonesian Economic Studies 43(3): 341-363.

Welch, A.R. (2007) 'Blurred Vision?: Public and Private Higher Education in Indonesia', Higher Education 54(5): 665-687.

Woo, J.Y. and Heo, H. (2009) 'Corruption and Foreign Direct Investment Attractiveness in Asia', Asian Politics \& Policy 1(2): 223-238.

World bank (2003) Combating Corruption in Indonesia: Enhancing Accountability for Development, World Bank, East Asia Poverty Reduction and Economic Management Unit, Washington D.C.

World Bank (2007) Doing Business, 2007, The World Bank, Washington, DC.

World Bank (2009) Doing Business, 2009, The World Bank, Washington D.C.

Zhang, K.H. (2001) 'Does Foreign Direct Investment Promote Economic Growth? Evidence from East Asia and Latin America', Contemporary Economic Policy 19(2): 175-185.

Zhou, Y. and Lall, S. (2005) 'The Impact of China's FDI surge on FDI in South-East Asia: a Panel Data Analysis for 1986-2001', Transnational Corporations 14(1): 4066. 


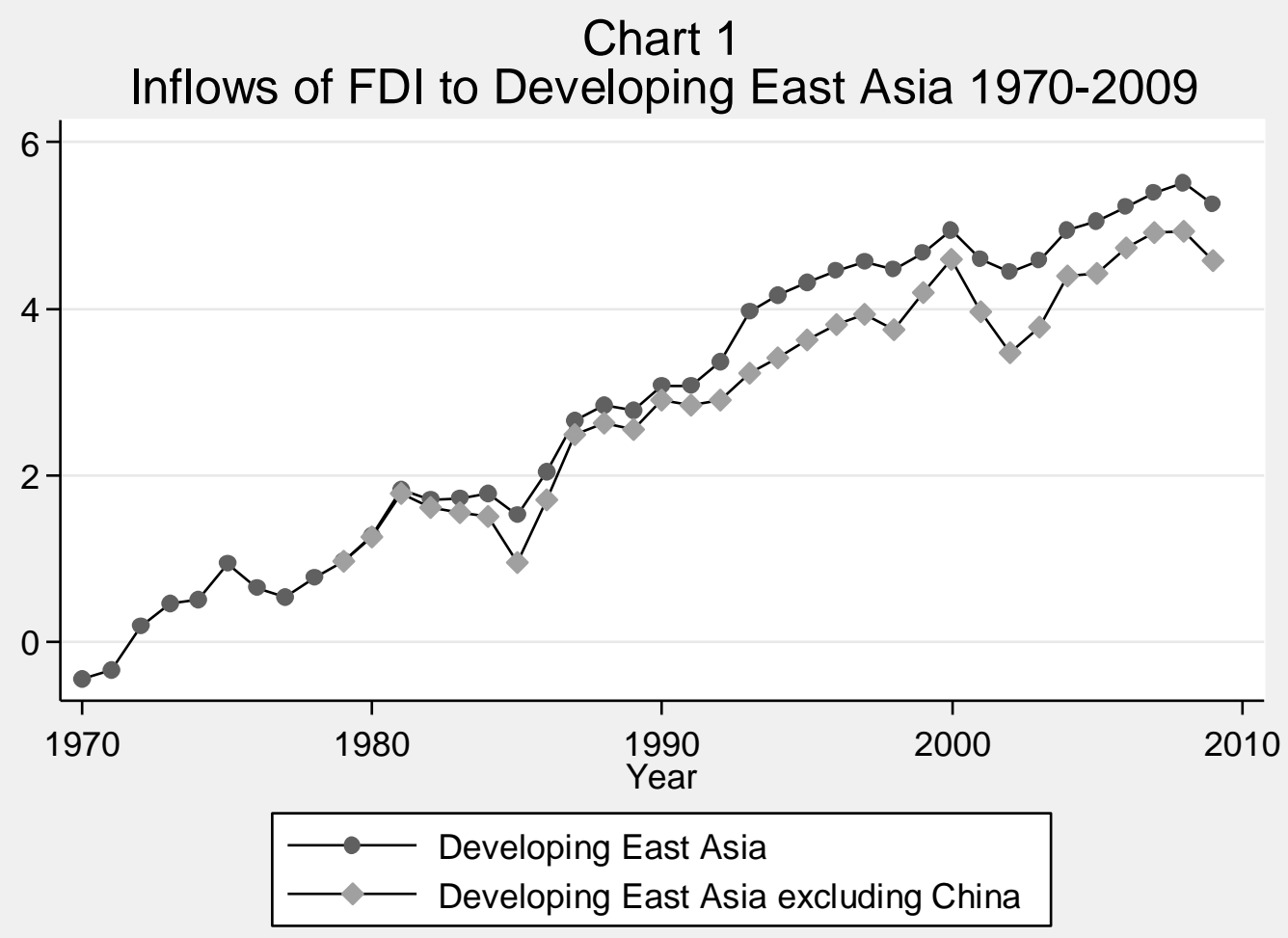

Data: The website of UNCTAD;

Until 2008, the data are from Interactive database

http://www.unctad.org/Templates/Page.asp?intItemID=3199\&lang=1

For 2009, UNCTAD( 2010)

http://www.unctad.org/Templates/webflyer.asp?docid=13423\&intItemID=2068\&1 $\underline{\text { ang }=1 \& \text { mode }=\text { downloads }}$ 
TABLE 1 The Stock of Inward FDI as Percent of GDP

\begin{tabular}{lrrrrrrr}
\hline & 1980 & 1985 & 1990 & 1995 & 2000 & 2005 & 2009 \\
\hline China/Hong Kong & 53.37 & 55.01 & 46.33 & 36.47 & 47.44 & 32.95 & 27.06 \\
Taiwan & 5.69 & 4.62 & 5.91 & 5.75 & 6.08 & 12.13 & 12.75 \\
Indonesia & 5.73 & 5.98 & 6.95 & 9.32 & 15.20 & 14.41 & 13.48 \\
Korea & 1.78 & 1.87 & 1.97 & 1.84 & 7.45 & 13.25 & 13.31 \\
Malaysia & 20.33 & 22.80 & 22.57 & 31.15 & 56.24 & 32.23 & 39.01 \\
Philippines & 2.82 & 5.98 & 10.22 & 13.69 & 23.92 & 15.17 & 14.63 \\
Singapore & 45.66 & 60.03 & 82.57 & 78.21 & 119.26 & 162.44 & 193.98 \\
Thailand & 3.03 & 5.14 & 9.66 & 10.53 & 24.38 & 34.24 & 37.52 \\
Viet Nam & 59.10 & 30.25 & 25.49 & 34.48 & 66.07 & 58.93 & 51.93 \\
& & & & & & & \\
Northeast Asia & 41.85 & 38.91 & 25.90 & 20.96 & 32.11 & 26.01 & 25.35 \\
Southeast Asia & 9.44 & 12.54 & 18.09 & 22.46 & 44.47 & 44.80 & 46.34 \\
\hline
\end{tabular}

Notes: For China/Hong Kong, the ratios are calculated by dividing the sum of FDI stocks of the two economies by the sum of GDP, which are obtained from International Financial Statistics, IMF. GDP reported in national currency is converted into US dollars by using the exchange rates reported by IMF (annual average). This procedure exaggerates the combined ratio because double counting of FDI is not eliminated, but the gross exaggeration of the Hong Kong ratio is eliminated.

Data: The website of UNCTAD;

Until 2008, the data are from Interactive database http://www.unctad.org/Templates/Page.asp?intItemID=3199\&lang=1 For 2009, UNCTAD (2010) and web annex tables http://www.unctad.org/Templates/webflyer.asp?docid=13423\&intItemID=2068\&1 ang $=1 \&$ mode $=$ downloads http://www.unctad.org/Templates/Page.asp?intItemID=5545\&lang=1 
TABLE 2 The Ratio of FDI inflow to Gross Capital Formation (\%) - Period Averages ${ }^{\text {a }}$ 1980-

\begin{tabular}{|c|c|c|c|c|c|c|}
\hline & 1984 & 1985-1989 & 1990- 1994 & 1995-1999 & 2000-2004 & $2005-2008$ \\
\hline China/Hong Kong & 2.30 & 4.35 & 10.26 & 13.63 & 12.58 & 9.27 \\
\hline Taiwan & 1.19 & 3.52 & 2.19 & 2.49 & 3.78 & 6.59 \\
\hline Indonesia & 0.88 & 1.70 & 3.93 & 5.69 & -2.41 & 7.12 \\
\hline Korea & 0.40 & 1.18 & 0.60 & 2.57 & 3.37 & 2.03 \\
\hline Malaysia & 12.59 & 9.87 & 19.99 & 16.22 & 11.56 & $18.42^{\mathrm{b}}$ \\
\hline Philippines & 2.04 & 7.23 & 7.90 & 8.56 & 7.25 & 11.68 \\
\hline Singapore & 18.86 & 29.22 & 27.87 & 38.96 & 62.72 & 63.66 \\
\hline Thailand & 2.67 & 4.55 & 4.33 & 8.91 & 13.90 & 14.53 \\
\hline Vietnam & - & $0.16^{\mathrm{c}}$ & 34.36 & 26.00 & 11.24 & 17.84 \\
\hline Northeast Asia ${ }^{\mathrm{d}}$ & 1.79 & 3.46 & 5.90 & 9.57 & 10.06 & 8.07 \\
\hline Southeast Asia $\stackrel{\underline{d}}{ }$ & 5.31 & 7.16 & 10.33 & 15.28 & 15.46 & 18.69 \\
\hline
\end{tabular}

Source: The website of UNCTAD, Foreign Direct Investment database

The website of World Bank, World databank

The website of National Statistics, Republic of China (Taiwan)

Note: ${ }^{a}$ The ratio of the period-sum of FDI inflow to the period-sum of gross capital formation.

b 2005 to 2007 .

${ }^{\mathrm{c}} 1986$ to 1989.

The figures are calculated as the ratio as the period-sum of FDI inflow to the period-sum of gross capital formation.

Countries other than those listed above were dropped from the aggregation if the data on their FDI inflows or gross capital formation were not available. The effect on the aggregate ratios was small. 
TABLE 3 The regional averages and country levels of the ranking of the Ease of Doing Business

\begin{tabular}{lrrr}
\hline & 2006 & 2008 & 2010 \\
\hline China & 108 & 90 & 89 \\
Hong Kong & 6 & 4 & 3 \\
Taiwan & 43 & 58 & 46 \\
Indonesia & 131 & 127 & 122 \\
Korea & 23 & 22 & 19 \\
Malaysia & 25 & 25 & 23 \\
Philippines & 121 & 136 & 144 \\
Singapore & 2 & 1 & 1 \\
Thailand & 19 & 19 & 12 \\
Vietnam & 98 & 87 & 93 \\
& & & \\
Northeast Asia & 45 & 44 & 40 \\
Southeast Asia & 66 & 66 & 65 \\
Latin America & 91 & 99 & 105 \\
Africa & 130 & 136 & 137 \\
\hline
\end{tabular}

Source: World Bank (2007b) and (2009); the website of World Bank http://www.doingbusiness.org/

Note: In 2007, 2009, and, 2010, Doing Business reports adjusted the ranking of the ease of doing business of the previous years for changes in methodology, data corrections, and addition of new economies. These are the adjusted rankings. 
TABLE 4 The Corruption Perceptions Index in Developing Regions.

\begin{tabular}{lll}
\hline & 2001 & 2009 \\
\hline China & 3.5 & 3.6 \\
Hong Kong & 7.9 & 8.2 \\
Taiwan & 5.9 & 5.6 \\
Indonesia & 1.9 & 2.8 \\
Korea & 4.2 & 5.5 \\
Malaysia & 5.0 & 4.5 \\
Philippines & 2.9 & 2.4 \\
Singapore & 9.2 & 9.2 \\
Thailand & 3.2 & 3.4 \\
Vietnam & 2.6 & 2.7 \\
& & \\
& & \\
Northeast Asia & 5.38 & 5.73 \\
Southeast Asia & 4.13 & 4.17 \\
Latin America & 3.75 & 3.56 \\
Africa & 3.24 & 2.85 \\
\hline
\end{tabular}

Source: the website of Transparency International, http://www.transparency.org/

Northeast Asia; China, Hong Kong, Korea, and Taiwan

Southeast Asia; Indonesia, Malaysia, Philippines, Singapore, Thailand, and Vietnam 
Table 5 Ratio of Actual Inward FDI Stock to Predicted Stock ${ }^{\mathrm{a}}$, 1980-005 Eight East Asian Countries

\begin{tabular}{lcccccc}
\hline \multicolumn{1}{c}{$\begin{array}{c}\text { Host } \\
\text { Country }\end{array}$} & 1980 & 1985 & 1990 & 1995 & 2000 & 2005 \\
\hline & & & & & & \\
China $^{\mathrm{a}}$ & 3.46 & 2.89 & 1.95 & 2.10 & 1.34 & 1.19 \\
Indonesia $_{\text {Korea }}$ & 0.27 & 0.31 & 0.36 & 0.52 & 0.27 & 0.40 \\
Malaysia & 0.10 & 0.12 & 0.34 & 0.25 & 0.45 & 1.04 \\
Philippines & 0.88 & 1.36 & 1.77 & 1.08 & 0.99 & 0.57 \\
Singapore & 0.11 & 0.32 & 0.54 & 1.05 & 0.80 & 0.37 \\
Taiwan & 0.31 & 0.47 & 1.03 & 1.43 & 1.27 & 1.72 \\
Thailand & 0.28 & 0.33 & 1.29 & 0.66 & 0.52 & 0.76 \\
& 0.13 & 0.23 & 1.06 & 0.68 & 0.62 & 1.00 \\
\hline
\end{tabular}

${ }^{\mathrm{a} P r e d i c t e d ~ f r o m ~ E q u a t i o n ~(1) ~}$

${ }^{\mathrm{b}}$ Including Hong Kong 
TABLE 6 Shares of Industries in Employment by All Nonbank Affiliates of US Parents in 2007.

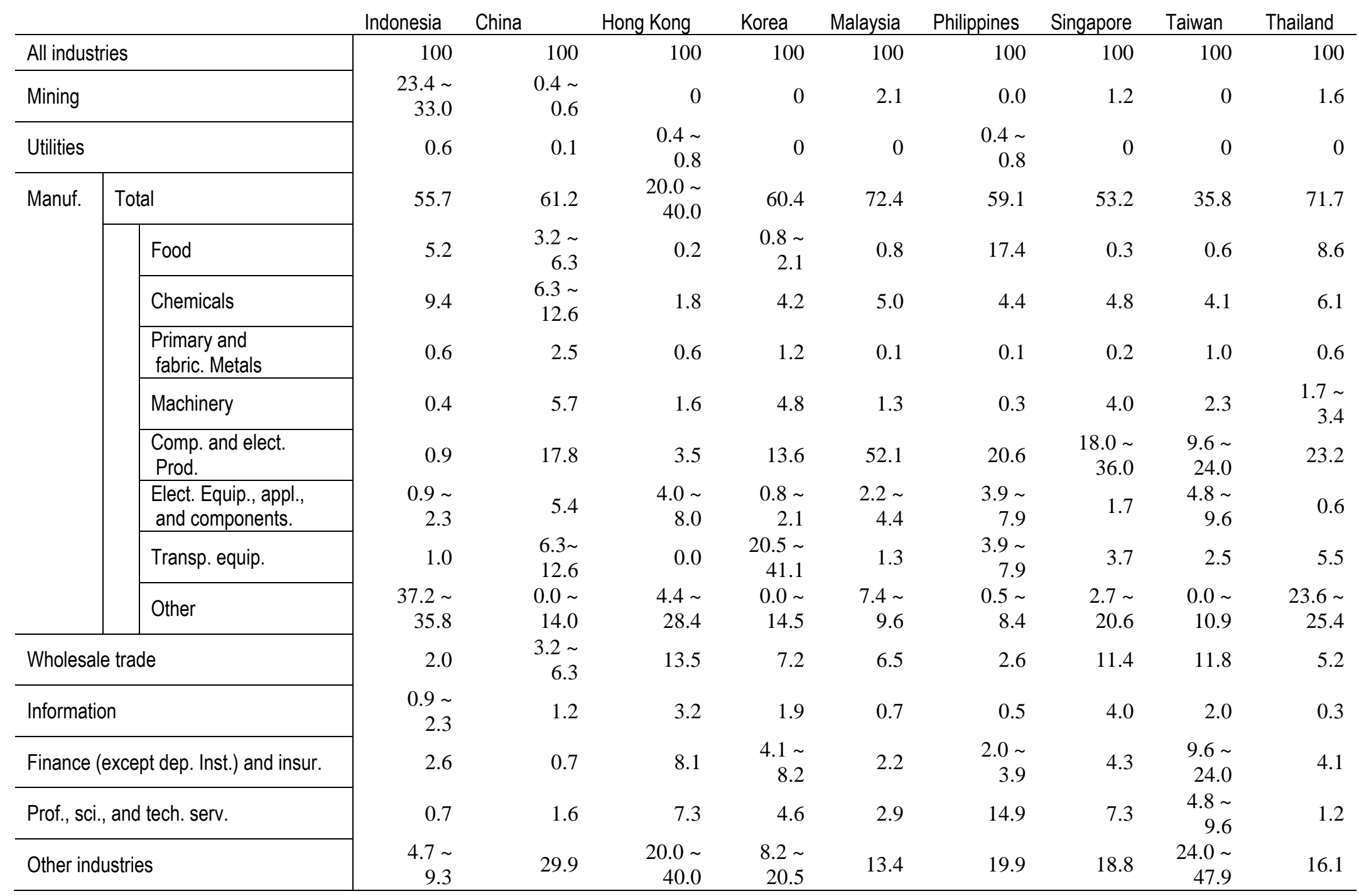


Source: US BEA (2009). Note: 0 indicates fewer than 500 employees. Some shares, such as for Mining in Indonesia, can only be shown as ranges, because the numbers are suppressed in the source. 
TABLE 7 The Percent of Sales outside the Host Country by Majority-Owned Foreign Manufacturing Affiliates of US parents in 2004.

\begin{tabular}{ll}
\hline Indonesia & 20.93 \\
China & 31.13 \\
Hong Kong & 50.93 \\
Korea & 14.95 \\
Malaysia & 72.19 \\
Philippines & 69.24 \\
Singapore & 59.90 \\
Taiwan & 41.40 \\
Thailand & 44.10 \\
\hline
\end{tabular}

Data: The website of the BEA; US Direct Investment Abroad 2004 Final Benchmark Data

Note: Sales outside the host country are total sales by affiliates minus local sales by affiliates. 
TABLE 8 Educational Attainment of the Total Population, 15 and over in East Asian Countries

\begin{tabular}{|c|c|c|c|c|c|}
\hline & \multirow[b]{2}{*}{$\begin{array}{c}\text { No } \\
\text { Schooling }\end{array}$} & \multicolumn{2}{|c|}{ Completion } & $\begin{array}{c}\text { Ratio } \\
\text { Tertiary/ }\end{array}$ & \multirow[b]{2}{*}{$\begin{array}{l}\text { Average Year } \\
\text { of Schooling }\end{array}$} \\
\hline & & Secondary & Tertiary & Secondary & \\
\hline Indonesia & 17.3 & 22.8 & 1.4 & 0.06 & 6.24 \\
\hline China & 6.5 & 46.0 & 5.2 & 0.11 & 8.17 \\
\hline $\begin{array}{l}\text { Hong } \\
\text { Kong }\end{array}$ & 12.5 & 39.5 & 6.7 & 0.17 & 10.37 \\
\hline Korea & 3.6 & 37.8 & 16.2 & 0.43 & 11.85 \\
\hline Malaysia & 8.5 & 38.9 & 4.7 & 0.12 & 10.14 \\
\hline Philippines & 4.2 & 21.3 & 22.9 & 1.08 & 8.97 \\
\hline Singapore & 8.2 & 22.3 & 10.7 & 0.48 & 9.14 \\
\hline Taiwan & 2.4 & 32.5 & 10.2 & 0.31 & 11.34 \\
\hline Thailand & 11.7 & 14.6 & 11.1 & 0.76 & 7.50 \\
\hline
\end{tabular}

Source: Barro-Lee web site (http://barrolee.com) and Barro and Lee (2010).

TABLE 9 R\&D as a share of GDP and in US affiliates.

\begin{tabular}{|c|c|c|c|c|}
\hline & \multicolumn{2}{|c|}{$\begin{array}{l}\text { R\&D as a share } \\
\text { of GDP }\end{array}$} & \multirow[t]{2}{*}{$\begin{array}{l}\text { R\&D as a percent } \\
\text { of employee } \\
\text { compensation in } \\
\text { US majority } \\
\text { affiliates } \\
2004\end{array}$} & \multirow[t]{2}{*}{$\begin{array}{l}\text { R\&D in US\$ per } \\
\text { employee in US majority } \\
\text { affiliates } \\
2004\end{array}$} \\
\hline & 2000 & 2005 & & \\
\hline China & 0.90 & 1.33 & 14.9 & 1,492 \\
\hline Hong Kong & -- & -- & 5.7 & 1,766 \\
\hline Indonesia & 0.07 & 0.05 & 0.6 & 80 \\
\hline Malaysia & 0.49 & -- & 11.2 & 1,484 \\
\hline Philippines & -- & 0.12 & 6.7 & 521 \\
\hline Korea & 2.39 & 2.98 & 9.6 & 3,462 \\
\hline Singapore & 1.88 & 2.30 & 19.0 & 6,394 \\
\hline Taiwan & -- & -- & 19.3 & 4,847 \\
\hline Thailand & 0.25 & 0.23 & 2.1 & 200 \\
\hline
\end{tabular}

Source: R\&D as a share of GDP from UNESCO

http://stats.uis.unesco.org/unesco/TableViewer/download.aspx

R\&D in US affiliates from U.S. Bureau of Economic Analysis (2008), Tables III.J1, III.H5, and III.H3. 


\section{APPENDIX}

TABLE A1 Studies comparing foreign and domestic plants in Indonesian Manufacturing.

\begin{tabular}{|c|c|c|c|}
\hline Author(s) & Year & $\begin{array}{l}\text { Dependent } \\
\text { variable }\end{array}$ & Main result \\
\hline \multicolumn{4}{|c|}{ Productivity } \\
\hline Takii (2004) & 1995 & TFP & $\begin{array}{l}\text { Foreign firms have high } \\
\text { productivity. Wholly } \\
\text { foreign owned relatively } \\
\text { high, new foreign firms } \\
\text { relatively low } \\
\text { productivity. }\end{array}$ \\
\hline $\begin{array}{l}\text { Takii and } \\
\text { Ramstetter } \\
(2005)\end{array}$ & $1975-2001$ & $\begin{array}{l}\text { Labor } \\
\text { productivity }\end{array}$ & $\begin{array}{l}\text { Foreign firms have high } \\
\text { productivity. The } \\
\text { difference varies by time } \\
\text { and industry. }\end{array}$ \\
\hline $\begin{array}{l}\text { Okamoto and } \\
\text { Sjöholm } \\
(2005)\end{array}$ & $1990-95$ & TFP & $\begin{array}{l}\text { Foreign firms have high } \\
\text { growth. }\end{array}$ \\
\hline $\begin{array}{l}\text { Arnold and } \\
\text { Javorcik } \\
(2009)\end{array}$ & 1983-1996 & TFP & $\begin{array}{l}\text { Foreign acquisitions of } \\
\text { domestic plants increase } \\
\text { productivity. }\end{array}$ \\
\hline \multicolumn{4}{|c|}{ Export } \\
\hline $\begin{array}{l}\text { Ramstetter } \\
\text { (1999) }\end{array}$ & $\begin{array}{l}1990 \\
1992 \\
1994\end{array}$ & $\begin{array}{l}\text { Export } \\
\text { intensities }\end{array}$ & $\begin{array}{l}\text { Foreign firms have high } \\
\text { export intensities. }\end{array}$ \\
\hline $\begin{array}{l}\text { Sjöholm } \\
\text { (2003b) }\end{array}$ & 1996 & Export & $\begin{array}{l}\text { Foreign firms relatively } \\
\text { able to start export. }\end{array}$ \\
\hline $\begin{array}{l}\text { Sjöholm and } \\
\text { Takii (2008) }\end{array}$ & $1990-2000$ & Export & $\begin{array}{l}\text { Foreign firms relatively } \\
\text { able to start export. }\end{array}$ \\
\hline $\begin{array}{l}\text { Lipsey and } \\
\text { Sjöholm } \\
\text { (2004a) }\end{array}$ & 1996 & $\begin{array}{l}\text { Labor market } \\
\text { Wages per } \\
\text { employee }\end{array}$ & $\begin{array}{l}\text { Foreign firms pay high } \\
\text { wages. }\end{array}$ \\
\hline $\begin{array}{l}\text { Lipsey and } \\
\text { Sjöholm } \\
(2006)\end{array}$ & 1975-1999 & $\begin{array}{l}\text { Wages per } \\
\text { employee }\end{array}$ & $\begin{array}{l}\text { Foreign firms pay high } \\
\text { wages. }\end{array}$ \\
\hline $\begin{array}{l}\text { Lipsey, } \\
\text { Sjöholm, and } \\
\text { Sun }(2010)\end{array}$ & $1975-2005$ & $\begin{array}{l}\text { Growth in } \\
\text { employment }\end{array}$ & $\begin{array}{l}\text { Foreign firms have high } \\
\text { growth in employment. }\end{array}$ \\
\hline
\end{tabular}


TABLE A2 Studies on Spillovers from FDI in Indonesian Manufacturing.

\begin{tabular}{|c|c|c|c|}
\hline Author(s) & Year & $\begin{array}{l}\text { Dependent } \\
\text { variable }\end{array}$ & Main result \\
\hline $\begin{array}{l}\text { Blomström } \\
\text { and Sjöholm } \\
\text { (1999) }\end{array}$ & 1991 & $\begin{array}{l}\text { Value added } \\
\text { per employee }\end{array}$ & $\begin{array}{l}\text { Positive } \\
\text { spillovers }\end{array}$ \\
\hline $\begin{array}{l}\text { Sjöholm } \\
\text { (1999a) }\end{array}$ & $\begin{array}{l}1980 \\
1991\end{array}$ & $\begin{array}{l}\text { Growth in } \\
\text { value added } \\
\text { Value added } \\
\text { per employee }\end{array}$ & $\begin{array}{l}\text { Positive } \\
\text { spillovers }\end{array}$ \\
\hline $\begin{array}{l}\text { Sjöholm } \\
\text { (1999b) }\end{array}$ & $\begin{array}{l}1980 \\
1991\end{array}$ & $\begin{array}{l}\text { Growth in } \\
\text { value added } \\
\text { Value added } \\
\text { per employee }\end{array}$ & $\begin{array}{l}\text { Positive } \\
\text { spillovers }\end{array}$ \\
\hline $\begin{array}{l}\text { Todo and } \\
\text { Miyamoto } \\
\text { (2002) }\end{array}$ & $1995-97$ & $\begin{array}{l}\text { Value added } \\
\text { per employee }\end{array}$ & $\begin{array}{l}\text { Positive } \\
\text { spillovers }\end{array}$ \\
\hline $\begin{array}{l}\text { Lipsey and } \\
\text { Sjöholm } \\
(2004 b)\end{array}$ & 1996 & $\begin{array}{l}\text { Wages per } \\
\text { employee }\end{array}$ & $\begin{array}{l}\text { Positive } \\
\text { spillovers }\end{array}$ \\
\hline Takii (2005) & $1990-95$ & Value added & $\begin{array}{l}\text { Positive } \\
\text { spillovers }\end{array}$ \\
\hline $\begin{array}{l}\text { Blalock and } \\
\text { Gertler } \\
(2008)\end{array}$ & $1988-96$ & Output & $\begin{array}{l}\text { Positive } \\
\text { spillovers }\end{array}$ \\
\hline $\begin{array}{l}\text { Temenggung } \\
\text { (2008) }\end{array}$ & $1975-2000$ & Output & $\begin{array}{l}\text { Positive } \\
\text { spillovers }\end{array}$ \\
\hline $\begin{array}{l}\text { Blalock and } \\
\text { Gertler } \\
(2009)\end{array}$ & $1988-96$ & Output & $\begin{array}{l}\text { Positive } \\
\text { spillovers }\end{array}$ \\
\hline Takii (2009) & $1990-1995$ & $\begin{array}{l}\text { Value added, } \\
\text { wages }\end{array}$ & $\begin{array}{l}\text { Positive } \\
\text { spillovers }\end{array}$ \\
\hline
\end{tabular}

